\title{
Variants
}

Scholarship

$12-13$ | 2016

Varia

\section{David C. Parker, Textual Scholarship and the Making of the New Testament: The Lyell Lectures Oxford Trinity \\ Term 2011}

\section{Geert Lernout}

\section{(2) OpenEdition}

Electronic version

URL: http://journals.openedition.org/variants/313

DOI: $10.4000 /$ variants.313

ISSN: 1879-6095

\section{Publisher}

European Society for Textual Scholarship

\section{Printed version}

Date of publication: 31 December 2016

Number of pages: 237-242

ISSN: 1573-3084

\section{Electronic reference}

Geert Lernout, « David C. Parker, Textual Scholarship and the Making of the New Testament: The Lyell Lectures Oxford Trinity Term 2017 », Variants [Online], 12-13 | 2016, Online since 01 May 2017, connection on 25 September 2020. URL : http://journals.openedition.org/variants/313 ; DOI : https:// doi.org/10.4000/variants.313

This text was automatically generated on 25 September 2020 .

The authors 


\title{
David C. Parker, Textual Scholarship and the Making of the New Testament: The Lyell Lectures Oxford Trinity Term 2011
}

\author{
Geert Lernout
}

\section{REFERENCES}

David C. Parker. Textual Scholarship and the Making of the New Testament: The Lyell Lectures Oxford Trinity Term 2011. Oxford: Oxford University Press, 2012. 208 pp. ISBN 978-0-19965781-0.

1 Despite the enormous importance of the Bible and more specifically the New Testament in Western culture, scholarship on the text has always been theologically suspect, as Erasmus found out when in 1516 he published his edition of the Greek text under the title Novum Instrumentum. At the same time, an edition of the New Testament was always been the ambition of the greatest textual scholars. Richard Bentley planned but never finished an edition of the text as it was at the time of the Council of Nicea; a century later Karl Lachmann published a new text in two slightly different editions. Both of these scholars worked with a limited number of manuscripts, but the world has changed since then.

2 In the Trinity Term 2011 the bible scholar and editor of a critical edition of the Gospel of John and of Paul's letters, David C. Parker gave the five Lyell lectures at Oxford under the title "Describing the New Testament". The title was a fair description. As he explains in the introduction to the published version of the lectures, he wanted to use the verb in another more punning meaning than the obvious one. Most people who think or write about the Christian part of the Bible tend to ignore or deny that scribes were involved in the text's production: "the concept of the modern printed book has 
become so prevalent that for most users it has driven out other, better informed understandings of the way it came into being and survived" (1). Parker wants to "rescribe" the holy book by reversing this denial of its manuscript tradition: "The New Testament is a collection of books which has come into being as a result of technological developments and the new ideas which both prompted and were inspired by them" (3).

3 In the first chapter/lecture he opens his discussion of the "general procedures" by deploring the fact that for some reason the term "bibliography" is not applied in studies of the bible, so he replaces the term by the general name of textual scholarship. He then distinguishes work, text and document as different objects, of interest to different groups of bible scholars. One of the special problems confronting the textual scholar of the New Testament is the enormous number of textual variants in an enormously large number of manuscripts. Parker gives the example of a single chapter (18) of the Gospel of John, contained in no less than 1500 manuscripts:

4 There are 1,186 readings which are supported by a minority of manuscripts. This amounts to about thirty in every verse. As many as 555 are found in a single manuscript, 163 have the support of two manuscripts, and 91 are attested by three manuscripts. Only twenty readings have the support of more than one hundred manuscripts (15-16).

5 Apart from the sheer magnitude of the manuscript record, we should also question our modern expectations about what to expect in texts that were first written down at a time when no two identical copies did or could exist and when the relationship between oral and written forms of language was different than it is today. The twentyseven books of the Greek New Testament only rarely appeared together in a single manuscript: to some extent we can say that it was the invention of printing in the Latin West that really established the New Testament canon in its present order.

6 Parker is a textual scholar in a field where this is a minority field and where textual issues are often totally unknown: he tells us that when he showed a high resolution image of a Greek manuscript to a New Testament scholar, his colleague thought it was "a badly written modern student exercise" (13). As he also explains, in recent decades New Testament scholarship has gone through a series of transformations with reader response theory as one of its latest incarnations. The trouble with this approach is that it is based on interaction with a text that is never questioned: these scholars may believe that in this text they are interacting with the apostle Paul or with the evangelists, but in reality "they are in debate with the result of two thousand years of development" (19). Parker does not advocate a return to the nineteenth century optimism of ever reaching an original or authorial text, but he suggests a reappraisal of what it is that textual scholars do and a redefinition of the nature of a written work (as a process and not an object). In the case of the New Testament, what Parker wants to establish in the Münster-Birmingham edition is an "Initial Text" for each of the books of the New Testament, "the form of the text from which the surviving copies are descended" (25) and this is definitely not an authorial text.

7 The second lecture addresses the question: what is a New Testament manuscript? First of all, there are very many of them, as we have seen. As of May 2011 there were 5,606 manuscripts that are numbered because they are included in the authoritative Gregory-Aland list. Parker describes the different kinds in this list: the papyri, the 
majuscules (on parchment), the minuscules (parchment and paper) and the lectionaries.

8 In each of these cases Parker shows the complexities of the situation facing an editor of the text: in the case of the papyri he mentions the Bodmer Miscellaneous Codex which contains a few canonical texts amid a selection of decidedly unorthodox writings. The list of majuscules is also eclectic: Parker mentions an ostracon with the text about the adulterous woman in Sahidic, a passage that is missing in the Sahidic manuscripts of the Gospel of John, making it our only witness of that contentious passage in this language. In the largest groups of minuscule manuscripts, Parker discusses the problem of including bible commentaries in this list, each with their own sometimes very distinctive formats, such as the catena, which is a compilation of commentaries on passages in the text by different authorities, mostly church fathers. Parker also points out that quite a few of these catena manuscripts have not even been included in the list. In the case of one family of catenas on the Fourth Gospel consisting of twenty-two manuscripts, only five have been given a Gregory-Aland number.

In the conclusion to this chapter Parker sums up the problems involved in answering the question "when is a manuscript a copy of the New Testament?" and he shows that only a digital database of the kind that is being developed in Münster and in Birmingham allows us to address the question in new and more productive ways, especially when it concerns the early period when clearly the idea of a canon of the New Testament did not yet exist.

10 This leads to a discussion in the third lecture on the relationship between these manuscripts. Starting from the idea that these manuscripts offer us only one aspect of the lives of the early Christians, Parker considers the narratives that textual scholars create solely on the basis of the written documents. In this chapter too we begin by looking at concrete examples of the work by identified scribes and on the art work in biblical manuscripts, but Parker quickly moves to textual analysis and more specifically to the division of manuscripts into often geographical "families" and to the theoretical concept of Lachmann's stemmatics (Parker reminds us that Sebastiano Timpanaro demonstrated that the idea predated Lachmann).

11 The trouble with the Lachmannian approach is that no other text suffered so much from contamination than that of the New Testament and contamination is exactly what stemmatics cannot deal with, especially in the context of a tradition with so many surviving copies. Parker does a good job in showing that the traditional late-nineteenth century view of the history of the text (as in Westcott and Hort) was based on very little evidence in very few manuscripts but that continues to be taught today. The digital tools that we have now allow scholars to replace it with a digital version that is far more accurate: "We are at last able to make Lachmannian stemmatics workable in complex textual traditions" (84). Parker devotes the better part of this chapter to explaining what the "Münster Method" of digital comparison between manuscripts consists of. This method, which Parker later calls a Coherence-Based Genealogical Application and that had already been used in the edition of the Catholic epistles in the Novum Testamentum Graecum: Editio critica maior, is no more than an attempt to make Lachmannian stemmatology do what it was supposed to do.

12 The fourth lecture focuses on editing the New Testament, an endeavor that is remarkably rare, considering the enormous importance that Christian churches give to at least some of the statements that the books of the New Testament contain, 
sometimes on the basis of theological opinions that have little to do with textual matters, a theme that Parker had explored in an earlier book. ${ }^{1}$ The question remains: what is it that editors do? Is the work really the text that they produce and of which we can only say that never existed in precisely this form? For Parker, a critical edition is not the work, but "a description of the work in its different forms. It is a tool for understanding the work" (105). As a result, he believes that we do not yet have a truly critical edition of the New Testament and he is convinced that the Editio critica maior will be the first such initiative.

In his description of the procedures of this edition, Parker covers roughly the same terrain that he explored in the earlier chapters, beginning with a description of the manuscripts that have been taken into account, with as many of the Greek manuscripts as could be collected, digitalized and then encoded according to the TEI conventions, which enables the use in all kinds of contexts. With justified pride, Parker notes that the transcriptions of the Codex Sinaiticus have been used on four different websites, in four different formats. In addition to this database Parker sketches the difficulties in collecting quotations from the New Testament in the works of the Greek church fathers (which have not always been critically edited) and of the ancient versions, most urgently the Latin, Syriac and Coptic translations of the New Testament, sometimes based on versions that predate our oldest extant Greek manuscripts.

Parker gives four reasons why such a critical edition is useful and necessary. The work on such a project is an important impetus for concerted study: "Well over one hundred people are participating at any one time" (120). Secondly, the editing of the New Testament creates international cooperation and, thirdly, the resulting text will not only replace the existing standard editions, The Greek New Testament of the United Bible Societies and the Nestle-Aland Novum Testamentum Graece, but it will also affect the translations that are now based on them. Finally, the intense and innovative work on the Greek New Testament will develop new methodologies and, more concretely, its digital format may revolutionize editing in general: "The Editio critica maior is therefore not the completion of an era in scholarship, but the beginning of a new one" (124).

What this future of scholarship could look like is discussed in the final and fifth lecture and is of great interest to textual scholars working on other texts and to the readers of Variants. Parker makes a strong case for the revolution that is just beyond the horizon and that can be compared to Gutenberg's invention. We still edit on computers as though our screens are pages in a codex, while it is the very nature of what we call the New Testament (or any other work) that is changing in ways that we cannot fully comprehend yet.

In short sections Parker discusses the different aspects of this revolution. The mass digitization of texts is called the "most important event in humanities research today" (129) because it has made manuscripts available to more scholars than ever before. This is illustrated beautifully in the Virtual Manuscript Room, hosted by Birmingham and Münster, and of course in the British Library's efforts to digitalize the famous early bible pandects Codex Sinaiticus and Alexandrinus and many other of its sacred books. Parker discusses Sinaiticus as the "furthest we have gone so far with digitizing a manuscript" (134) and his description certainly supports that statement. Even more exciting are the New Testament digital transcriptions that make possible a new kind of edition, which Parker had called "baseless" in his fourth lecture: an apparatus without a base text, which will allow readers to take any witness as the base text. This is part of 
what the scholars involved in the Editio critica maior have developed as the Workspace for Collaborative Editing. Since this online editing tool was created for one of the most complex and difficult of texts, it will be useful for most other texts too. At the end of this chapter, Parker sums up the new way of thinking: "once the critical edition was the database, now it is the interface" (142). The conclusion sums up the major findings in the five lectures and the five discoveries he himself made in preparing and giving the lectures. The final one of these is a suitably general conclusion of the whole book and deserves to be quoted in full:

17 Finally, having started with the concept of text as a process, and with the distinction between documents, texts, and work, I believe that I have made some progress towards the goal of understanding the New Testament writings as a set of works containing many forms of text and no single definitive form, which may be described solely by the examination of the manuscripts in which those forms of text are found. (147)

This is a most lucid account of the ambitions of the Editio critica maior, but it is also a wonderfully clear survey of all the different dimensions of Greek bible criticism by one of the most important scholars in the field of New Testament studies.

PS: It was a genuine joy to find a beautiful sentence that I will cherish for a long time: "Paul is beginning in Birmingham and work on the Apocalypse has started in Wuppertal" (112).

\section{NOTES}

1. David C. Parker. The Living Text of the Gospels. Cambridge University Press, 1997. Ironically, the archive.org digital version of that book is now accompanied by a barely coherent rant from a supporter of Gail Riplinger, one of the leaders of the King James Only movement, which believes that textual scholars are all homosexual worshippers of the devil.

\section{AUTHORS}

\section{GEERT LERNOUT}

Geert Lernout teaches English and comparative literature at the University of Antwerp. He has published several books in English on the work of James Joyce and Friedrich Hölderlin and in Dutch on the history of the book, on Bach's Goldberg Variations, on the bible and on the role of religion in the United States. 